\title{
Absence of Shb impairs insulin secretion by elevated FAK activity in pancreatic islets
}

\author{
Ida Alenkvist", Oleg Dyachok*, Geng Tian, Jia Li, Saba Mehrabanfar, Yang Jin', \\ Bryndis Birnir ${ }^{1}$, Anders Tengholm and Michael Welsh
}

Department of Medical Cell Biology, Uppsala University, Box 571, Husargatan 3, 75123 Uppsala, Sweden 1 Department of Neuroscience, Uppsala University, Uppsala, Sweden

*(I Alenkvist and O Dyachok contributed equally to this work)
Correspondence should be addressed to A Tengholm or M Welsh Emails anders.tengholm@mcb.uu.se or michael.welsh@mcb.uu.se

\begin{abstract}
The Src homology-2 domain containing protein B (SHB) has previously been shown to function as a pleiotropic adapter protein, conveying signals from receptor tyrosine kinases to intracellular signaling intermediates. The overexpression of Shb in $\beta$-cells promotes $\beta$-cell proliferation by increased insulin receptor substrate (IRS) and focal adhesion kinase (FAK) activity, whereas Shb deficiency causes moderate glucose intolerance and impaired first-peak insulin secretion. Using an array of techniques, including live-cell imaging, patch-clamping, immunoblotting, and semi-quantitative PCR, we presently investigated the causes of the abnormal insulin secretory characteristics in Shb-knockout mice. Shb-knockout islets displayed an abnormal signaling signature with increased activities of FAK, IRS, and AKT. $\beta$-catenin protein expression was elevated and it showed increased nuclear localization. However, there were no major alterations in the gene expression of various proteins involved in the $\beta$-cell secretory machinery. Nor was Shb deficiency associated with changes in glucose-induced ATP generation or cytoplasmic $\mathrm{Ca}^{2+}$ handling. In contrast, the glucose-induced rise in CAMP, known to be important for the insulin secretory response, was delayed in the Shb-knockout compared with WT control. Inhibition of FAK increased the submembrane CAMP concentration, implicating FAK activity in the regulation of insulin exocytosis. In conclusion, Shb deficiency causes a chronic increase in $\beta$-cell FAK activity that perturbs the normal insulin secretory characteristics of $\beta$-cells, suggesting multi-faceted effects of FAK on insulin secretion depending on the mechanism of FAK activation.
\end{abstract}

\section{Key Words}

- Src homology 2

- FAK

- insulin secretion

- CAMP
Journal of Endocrinology (2014) 223, 267-275

\section{Introduction}

Src homology-2 domain containing protein B (SHB) is a pleiotropic adapter protein, generating signaling complexes in response to tyrosine kinase activation via multi-domain interactions (Annerén et al. 2003). These complexes are context dependent and exert different roles in different settings. SHB has been found to regulate apoptosis, proliferation, differentiation, and the cytoskeleton (Annerén et al. 2003). In insulin-secreting pancreatic $\beta$-cells, SHB overexpression not only increases focal adhesion kinase (FAK) and insulin receptor substrate 1/2 (IRS1/2) signaling (Welsh et al. 2002) and proliferation (Annerén 2002), but also increases apoptosis in response

Published by Bioscientifica Ltd. 
to stress (Welsh et al. 1999). FAK is a tyrosine kinase, operating in submembranous focal adhesions connecting the extracellular matrix with intracellular signal transduction and the cytoskeleton (Parsons 2003). Cues from both extracellular matrix proteins and intracellular signaling events stimulate FAK activity, which in turn acts as a scaffold in focal adhesions and activates various downstream signaling pathways, such as AKT and ERK (Parsons 2003). In $\beta$-cells, FAK has been shown to convey signals from the extracellular matrix (Hammar et al. 2004), promoting $\beta$-cell survival, and from glucose (Rondas et al. 2011, 2012, Arous et al. 2013), stimulating insulin secretion both in vitro and in vivo (Cai et al. 2012).

Absence of $S h b$ has no effect on $\beta$-cell proliferation, but reduces cell death in response to cytotoxic agents (Åkerblom et al. 2009, Mokhtari et al. 2009). In addition, Shb-deficient mice show mild glucose intolerance due to a reduction in insulin secretion (Åkerblom et al. 2009). The mechanisms underlying this secretory defect are unknown. Glucose stimulation of insulin secretion involves uptake and metabolism of the sugar, and the resulting production of ATP causes membrane depolarization by an inhibitory action on ATP-sensitive $\mathrm{K}^{+}$ channels (Rorsman \& Braun 2013). The depolarization activates voltage-dependent $\mathrm{Ca}^{2+}$ channels and the concomitant increase in the cytoplasmic $\mathrm{Ca}^{2+}$ concentration $\left(\left[\mathrm{Ca}^{2+}\right]_{\mathrm{i}}\right)$ triggers exocytosis of insulin secretory granules (Rorsman \& Braun 2013). Glucose metabolism also stimulates the generation of cAMP and other metabolic coupling factors, which amplify the $\mathrm{Ca}^{2+}$-triggered exocytosis response (Dyachok et al. 2008, Henquin 2009). The glucose response is typically biphasic with a pronounced first phase lasting a few minutes followed by a lower rate of secretion that is sustained or slowly increasing (second phase). Shb knockout seems to affect primarily the first phase of insulin secretion (Åkerblom et al. 2009).

In this study, we investigated whether the absence of $S h b$ was associated with changes in ATP generation, $\left[\mathrm{Ca}^{2+}\right]_{\mathrm{i}}, \mathrm{cAMP}$, and tyrosine kinase signaling and gene expression of certain exocytotic proteins in isolated islets. There were little abnormalities in Shb-knockout islets. However, we observed elevated constitutive FAK activity that provides an explanation for the similarly increased activities of AKT and $\beta$-catenin. Moreover, glucoseinduced cAMP elevation was delayed, a finding which probably underlies the reduced first-peak insulin secretion, and which may occur as a consequence of increased FAK activity in $S h b$-deficient islets.

\section{Materials and methods}

\section{Mice}

Two- to five-month-old WT and Shb-knockout mice (Kriz et al. 2007) on a mixed genetic background (FVBJ/C57Bl6/129Sv) were used for islet isolation. Approval for breeding and killing the mice had been given by the local animal ethics committee.

\section{Islet isolation}

The animals were killed and pancreata were removed and suspended in Hanks' solution (SVA, Uppsala, Sweden). Each pancreas was cut into pieces with scissors and subjected to collagenase digestion $(1 \mathrm{mg} / \mathrm{ml}$ Hanks per pancreas, Collagenase A, 10-154 121, Roche) for $20 \mathrm{~min}$ at $37^{\circ} \mathrm{C}$, on a shaking water bath, then washed twice with wash buffer (Ringer-acetate Fresenius-Kabi, Uppsala, Sweden, supplemented with $4.5 \mathrm{mM} \mathrm{NaHCO} 3,2.5 \mathrm{mM}$ glucose and penicillin-streptomycin), and suspended in Hanks' solution. The hand-picked islets were cultured at 5.6 or $11.1 \mathrm{mM}$ glucose in RPMI $1640+10 \%$ fetal bovine serum+antibiotics for at least $24 \mathrm{~h}$ before experimentation. For ATP and cAMP imaging experiments, the islets were infected for $1-2 \mathrm{~h}$ with adenovirus expressing the respective protein-based signaling biosensors at a concentration of 20 plaque-forming units/cell in a medium containing $2 \%(\mathrm{v} / \mathrm{v})$ serum, followed by washing with a regular complete medium and further culture for 16-20 h before use.

\section{Immunoblotting}

After 15 min incubation in Hanks' solution at $37^{\circ} \mathrm{C}, 30-50$ islets were washed with ice-cold PBS and directly lysed in SDS-sample buffer, boiled for $5 \mathrm{~min}$, and separated on SDS-PAGE. The proteins were electrophoretically transferred to Hybond-P filters (GE Healthcare, Uppsala, Sweden). The filters were blocked in 5\% BSA for $1 \mathrm{~h}$, after which they were probed with phospho-202/204 ERK; phospho-473 AKT; phospho-612 IRS1/2; phospho-Y397 FAK, AKT, IRS2, FAK; $\beta$-catenin; and ERK (Cell Signaling, Beverly, MA, USA for most antibodies; pYFAK and pYIRS, Invitrogen; ERK, Santa Cruz; $\beta$-catenin, Abcam, Cambridge, UK; and IRS2, Upstate Biotechnology, Lake Placid, NY, USA) antibodies. The bound antibodies were removed from filters by incubating for $40 \mathrm{~min}$ at $55^{\circ} \mathrm{C}$ in $2 \% \mathrm{w} / \mathrm{v}$ SDS and $0.1 \mathrm{mM} \beta$-mercaptoethanol. HRP-linked goat antirabbit or anti-mouse was used as a secondary antibody.

Published by Bioscientifica Ltd 
Immunodetection was performed as described for the ECL prime immunoblotting detection system (GE Healthcare) using the Kodak Imagestation 4000MM. The intensities of the bands were quantified by densitometric scanning using Kodak Digital Science ID software (Eastman Kodak).

\section{Gene expression analysis}

Total RNA was prepared by using the RNeasy Mini Kit (Qiagen) with on-column DNase digestion with RNaseFree DNase set (Qiagen), according to the manufacturer's descriptions. For RNA isolation, 30 islets/sample were collected, briefly washed in PBS, and then lysed and homogenized. RNA yield was determined using a spectrophotometer at $260 \mathrm{~nm}$. One-step quantitative real-time RT-PCR was carried out using the QuantiTect SYBR Green RT-PCR Kit (Qiagen) on a LightCycler (Roche Diagnostics).

The PCR conditions were according to kit supplier's instructions: RT $20 \mathrm{~min}$ at $50{ }^{\circ} \mathrm{C}$, denaturation $15 \mathrm{~min}$ at $95^{\circ} \mathrm{C}$, cycling: denaturation $15 \mathrm{~s}$ at $94^{\circ} \mathrm{C}$, annealing $30 \mathrm{~s}$ at $55-60^{\circ} \mathrm{C}$, and extension $30 \mathrm{~s}$ at $72^{\circ} \mathrm{C}$. Crossing point (Ct) values were determined with the LightCycler Software v3.5 (Roche Diagnostics). Gene expression was normalized by subtracting the corresponding $\beta$-actin Ct value. Statistical comparisons were made on normalized $\mathrm{Ct}$ values.

\section{Measurements of cytoplasmic ATP dynamics}

The islets were preincubated for $30-60 \mathrm{~min}$ in an experimental buffer containing $\mathrm{NaCl} 138 \mathrm{mM}, \mathrm{KCl}$ $4.8 \mathrm{mM}, \mathrm{MgCl}_{2} 1.2 \mathrm{mM}, \mathrm{CaCl}_{2} 1.3 \mathrm{mM}$, glucose $3 \mathrm{mM}$, HEPES $25 \mathrm{mM}$ (pH 7.40), and $0.5 \mathrm{mg} / \mathrm{ml} \mathrm{BSA}$. The islets were then placed on a poly-L-lysine-coated coverslip in the superfusion chamber on the thermostated stage of a total internal reflection fluorescence microscope (Eclipse Ti with a $60 \times, 1.45$-NA objective, Nikon, Japan). A diode-pumped solid-state laser (Cobolt $\mathrm{AB}$, Solna, Sweden) provided $491 \mathrm{~nm}$ excitation light and the emission was selected by a 527/27-nm (center wavelength/half-bandwidth) interference filter (Semrock, Rochester, NY, USA) and recorded by an EMCCD camera (DU-897; Andor, Belfast, UK) controlled by MetaFluor software (Molecular Devices, Sunnyvale, CA, USA). All imaging experiments were carried out at $37^{\circ} \mathrm{C}$, with a medium superfusion rate of $0.12-0.20 \mathrm{ml} / \mathrm{min}$ and with images acquired every $2-5 \mathrm{~s}$.

\section{Recordings of $\left[\mathrm{Ca}^{2+}\right]_{i}$}

For the measurements of $\left[\mathrm{Ca}^{2+}\right]_{\mathrm{i}}$, islets were pre-incubated for $30-40 \mathrm{~min}$ in the presence of $1 \mu \mathrm{mol} / \mathrm{l}$ acetoxymethyl ester of the $\mathrm{Ca}^{2+}$ indicator Fura-PE3. Imaging of the Fura-PE3-loaded cells was carried out with an inverted microscope equipped with a $40 \times 1.3-\mathrm{NA}$ objective (Nikon) and an epifluorescence illuminator (Cairn Research Ltd, Faversham, UK) connected through a $5 \mathrm{~mm}$ diameter liquid light guide to an Optoscan monochromator (Cairn Research Ltd) with a 150-W xenon arc lamp. The monochromator provided excitation light at 340 and $380 \mathrm{~nm}$, which was reflected by a 400-nm dichroic beam splitter, and emission was measured at $510 \mathrm{~nm} / 40 \mathrm{~nm}$ half-bandwidth using a CCD camera (Orca, Hamamatsu, Hamamatsu City, Japan) with an image intensifier (C8600, Hamamatsu). The Metafluor software (Molecular Devices) controlled the monochromator and the camera, acquiring image pairs every $2 \mathrm{~s}$ with $100-400 \mathrm{~ms}$ integration at each wavelength and $<1 \mathrm{~ms}$ for changing wavelength and slits. To minimize bleaching and photodamage, the monochromator slits were closed until the start of the next acquisition cycle. The ratio images $(340 / 380 \mathrm{~nm})$ were obtained after subtraction of background and $\left[\mathrm{Ca}^{2+}\right]_{\mathrm{i}}$ values calculated as previously described (Grynkiewicz et al. 1985).

\section{Real-time measurements of cAMP}

The measurements of the sub-plasma membrane concentration of cAMP were carried out with a CFP/YFP-based translocation reporter and TIRF microscopy as previously described (Tian et al. 2011). The microscope setup was the same as that described for ATP measurements except that CFP and YFP excitation was provided by the 457- and 515-nm lines of diode-pumped solid-state lasers (Cobolt), and fluorescence was detected at 485/25 and 560/40 nm (Semrock).

\section{Patch-clamp analysis of $\mathrm{Ca}^{2+}$ currents}

The electrophysiological recordings were done using whole-cell patch-clamp recordings of cells in intact islets. The extracellular solution contained $140 \mathrm{mM} \mathrm{NaCl}$, $3.6 \mathrm{mM} \mathrm{KCl}, 2 \mathrm{mM} \mathrm{NaHCO}, 0.5 \mathrm{mM} \mathrm{NaH} \mathrm{PO}_{4}, 5 \mathrm{mM}$ HEPES (pH 7.40 with $\mathrm{NaOH}$ ), and $2.6 \mathrm{mM} \mathrm{CaCl}_{2}$. Glucose was present at $5 \mathrm{mM}$ in all experiments. The pipette solution consists of $76 \mathrm{mM} \mathrm{K}_{2} \mathrm{SO}_{4}, 10 \mathrm{mM} \mathrm{NaCl}, 10 \mathrm{mM}$ $\mathrm{KCl}, 1 \mathrm{mM} \mathrm{MgCl}_{2}$, and $5 \mathrm{mM}$ HEPES (pH 7.35 with $\mathrm{KOH}$ ). In order to record only inward $\mathrm{Ca}^{2+}$ currents, outward currents were suppressed by the inclusion of tetraethylammonium chloride at a concentration of $20 \mathrm{mM}$ in the extracellular medium ( $\mathrm{NaCl}$ was correspondingly reduced to maintain isosmolarity) and by replacing $\mathrm{K}_{2} \mathrm{SO}_{4}$

Published by Bioscientifica Ltd. 
in the pipette-filling solution with an equimolar amount of $\mathrm{CsSO}_{4}$. The recording pipettes were made from borosilicate glass capillaries (Harvard Apparatus, Holliston, MA, USA) and had a resistance of 3-5 $\mathrm{M} \Omega$ when filled with the pipette solution. The holding potential was set at $-60 \mathrm{mV}$ and then stepped to the experimental potential for $200 \mathrm{~ms}$. The current recordings were done using an Axopatch 200B amplifier, filtered at $2 \mathrm{kHz}$, sampled at $10 \mathrm{~Hz}$ by an analog-to-digital converter, and stored in a computer. The recordings were then analyzed with the pClamp 9 software (Molecular Devices).

\section{Statistical analyses}

The means \pm s.E.M. for the indicated number of observations are given. For testing differences, Student's $t$-test was used (unpaired or paired depending on the experimental conditions) as indicated.

\section{Results}

\section{Characteristics of tyrosine kinase signal transduction in Shb-knockout islets}

As $S h b$ is a signal transduction protein downstream of tyrosine kinase receptors and as altered signaling characteristics were previously observed in $S h b$-deficient cells, we decided to investigate FAK, IRS1/2, AKT, and ERK signaling in $S h b$-knockout islets by using phospho-specific antibodies recognizing active forms of these signaling intermediates (Fig. 1). Basal FAK activity at $5.6 \mathrm{mM}$ glucose was elevated as a consequence of absence of Shb. The increase was modest (42\%) but typical for the level of increase previously observed as a consequence of $S h b$ deficiency (Funa et al. 2009, Gustafsson et al. 2013). Downstream of FAK in $\beta$-cells are IRS-proteins (Baron et al. 1998). We assessed IRS1/2 activity using an antibody that recognizes the phosphotyrosine characteristic of the active form of both proteins (pY612). On the basis of the total IRS2 protein reactivity on the blots, the predominant phospho-reactive component in the current setting appeared to be IRS2 (Fig. 1). IRS2 activity was increased by $19 \%$. AKT and ERK are downstream of both FAK and IRS2. AKT activity was increased by $51 \%$, whereas ERK activity showed a large variability with an average increase of $36 \%$ that failed to reach statistical significance.

One target of AKT is glycogen synthase kinase 3-beta (GSK-3b), which becomes inhibited through AKT phosphorylation (Woodgett 2005). GSK-3b is a negative regulator of $\beta$-catenin and consequently $\beta$-catenin levels
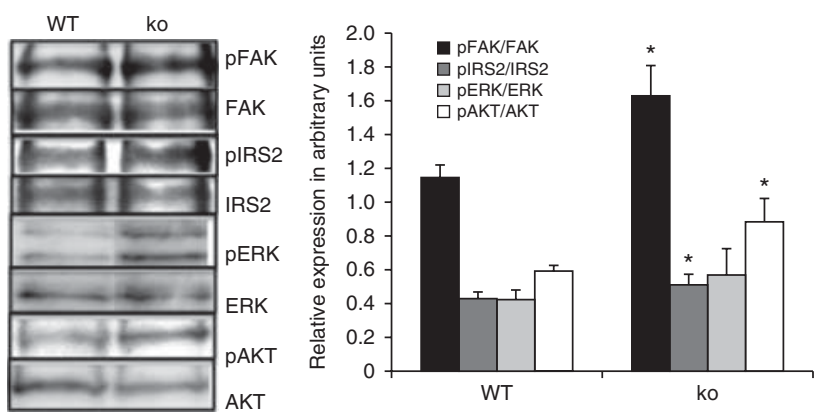

Figure 1

Activities of FAK, IRS2, AKT, and ERK in WT and Shb-knockout islets as determined by western blotting analysis using phospho-specific antibodies recognizing active forms. The isolated islets were cultured overnight in RPMI $1640+10 \%$ fetal bovine serum, incubated at $37^{\circ} \mathrm{C}$ for $15 \mathrm{~min}$ in Hanks' salt solution containing $5.6 \mathrm{mM}$ glucose before lysis, electrophoresis, blotting, and incubation with appropriate antibodies. Relative values after densitometry are given as means \pm S.E.M. for five to six separate experiments (separate islet isolation and blot). In the pERK and total ERK blots, bands from separate parts of the same blot with an identical exposure were juxtaposed. ${ }^{*} P<0.05$ with a paired Student's $t$-test.

increase and $\beta$-catenin translocates to the nucleus where it alters gene transcription upon AKT activation (Woodgett 2005). As AKT activity was increased in $S h b$-knockout islets, we found it relevant to investigate $\beta$-catenin levels and nuclear translocation (Fig. 2). These were both increased in Shb-deficient islets, suggesting that the increase in FAK activity has implications for $\beta$-catenindependent gene transcription via enhanced AKT activity.

\section{Gene expression of proteins involved in exocytosis}

We next determined gene expression levels of various proteins relevant to the exocytotic process using real-time RT-PCR. The genes analyzed were Rab3a, synaptosomalassociated protein 25 (Snap25), vesicle-associated membrane protein 2 (Vamp2), Munc18-1 (syntaxin-binding protein 1 (Stxbp1)), and Syntaxin1a (Stx1a) (Table 1). None of these were differentially expressed in $S h b$-knockout islets compared with control islets, suggesting that altered expression of these exocytosis proteins are not likely explanations for the reduced first-phase insulin secretory response.

\section{Sub-membrane ATP levels and intracellular $\mathrm{Ca}^{2+}$ handling in Shb-knockout islets}

To investigate whether abnormalities in glucose stimulussecretion coupling can explain the secretory defect, we measured the submembrane ATP concentration using

Published by Bioscientifica Ltd. 


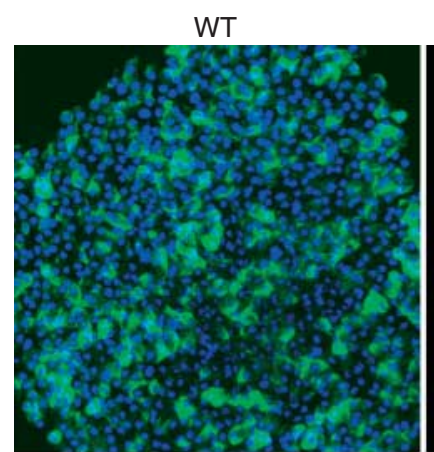

$100 \mu \mathrm{m}$
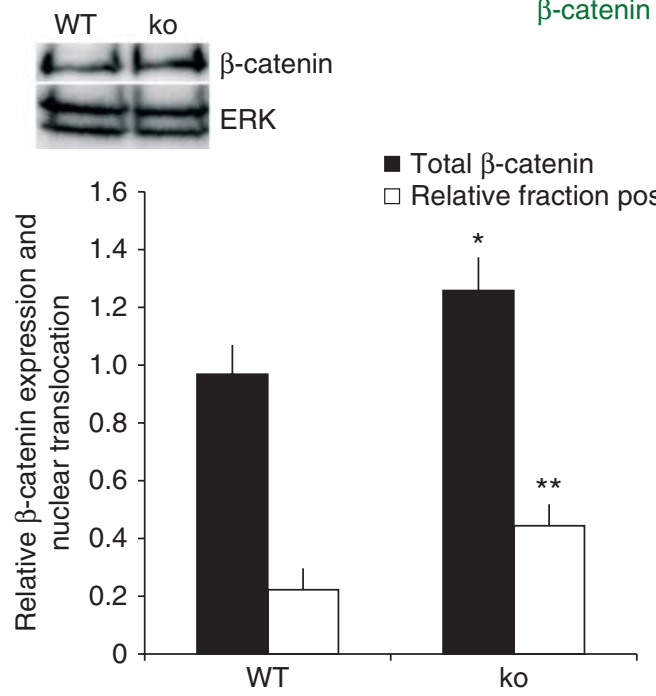

Figure 2

Contents and nuclear translocation of $\beta$-catenin in WT and Shb-knockout islets. For expression, islets were analyzed as shown in Fig. 1. Values are relative expression after normalization for total ERK. Nuclear translocation was determined as shown in images, in which DAPI-positive nuclei (blue) were also positive for $\beta$-catenin staining (green). Fractions of nuclei positive for $\beta$-catenin were quantified. Means \pm s.E.M. for six separate experiments are shown. ${ }^{*} P<0.05$ and ${ }^{*} P<0.01$ using a paired Student's $t$-test.

TIRF microscopy and the fluorescent ATP sensor Perceval in islets exposed to a step increase of the glucose concentration from 3 to $20 \mathrm{mM}$. This stimulation resulted in a pronounced rise in ATP (Fig. 3), which was of similar magnitude in both WT $(48 \pm 3 \%$ increase in Perceval fluorescence) and $S h b$-knockout (50 $\pm 2 \%)$ islets $(P>0.6)$, suggesting that the absence of $S h b$ does not impair the ability of $\beta$-cells to generate ATP in response to glucose stimulation.

The rise in sub-membrane ATP triggers depolarization and voltage-dependent $\mathrm{Ca}^{2+}$ influx in $\beta$-cells. The resulting increase in $\left[\mathrm{Ca}^{2+}\right]_{\mathrm{i}}$ was investigated as a potential explanation for the aberrant insulin secretory characteristics. Slight tendencies to lower $\left[\mathrm{Ca}^{2+}\right]_{i}$ in
Shb-knockout islets in the presence of both 3 and $20 \mathrm{mM}$ glucose did not reach statistical significance (Fig. 4). Moreover, closure of ATP-sensitive $\mathrm{K}^{+}$channels with $1 \mathrm{mM}$ tolbutamide resulted in similar increases in $\left[\mathrm{Ca}^{2+}\right]_{\mathrm{i}}$. Patch-clamp analysis of whole-cell $\mathrm{Ca}^{2+}$ currents in the $\beta$-cells of intact islets also failed to demonstrate any difference between WT and Shb-knockout cells (Fig. 5), suggesting that the defective insulin secretion is not due to alterations in intracellular $\mathrm{Ca}^{2+}$ handling.

\section{Glucose-induced cAMP generation is delayed in Shb-knockout islets}

First-peak insulin secretion has been found to be related with cAMP generation (Idevall-Hagren et al. 2010) and we therefore investigated the dynamics of glucose-induced cAMP generation. Interestingly, the rise in cAMP, triggered by an elevation of the glucose concentration from 3 to $20 \mathrm{mM}$, was delayed by $\sim 1 \mathrm{~min}$ in $S h b$-knockout islets compared with control (Fig. 6). This provides a potential explanation for the impaired first-peak insulin secretory response observed in these islets.

\section{Inhibition of FAK triggers rise in sub-membrane CAMP}

Increased FAK activity has previously been reported to stimulate insulin secretion in response to glucose stimulation (Rondas et al. 2011). We decided to address whether FAK activity can be related with insulin secretion also in the current setting by monitoring the submembrane cAMP concentration because active FAK has been shown to recruit a cAMP-degrading phosphodiesterase (Serrels et al. 2010, 2011). Addition of $10 \mu \mathrm{M}$ of the FAK inhibitor 14 (Golubovskaya et al. 2008, Gustafsson et al. 2013) to WT islets, and Shb-knockout islets exposed to $3 \mathrm{mM}$ glucose caused a progressive increase in the basal cAMP concentration (Fig. 6), suggesting that FAK indeed may exert negative control of cAMP signaling.

Table 1 Expression of genes coding for exocytotic proteins in Shb-knockout islets. Values are Ct values after subtracting the corresponding $\beta$-actin $\mathrm{Ct}$ values. Means \pm s.E.M. are shown for 6-11 separate experiments

\begin{tabular}{|c|c|c|}
\hline Gene & WT & Shb-knockout \\
\hline Rab3a & $5.04 \pm 0.42$ & $5.15 \pm 0.39$ \\
\hline Snap25 & $3.79 \pm 0.47$ & $4.09 \pm 0.31$ \\
\hline Munc18-1 (Stxbp1) & $3.99 \pm 0.25$ & $4.34 \pm 0.32$ \\
\hline Vamp2 & $2.86 \pm 0.61$ & $2.99 \pm 0.56$ \\
\hline Syntaxin1a (Stx1a) & $10.42 \pm 0.96$ & $10.25 \pm 0.97$ \\
\hline
\end{tabular}

Published by Bioscientifica Ltd 

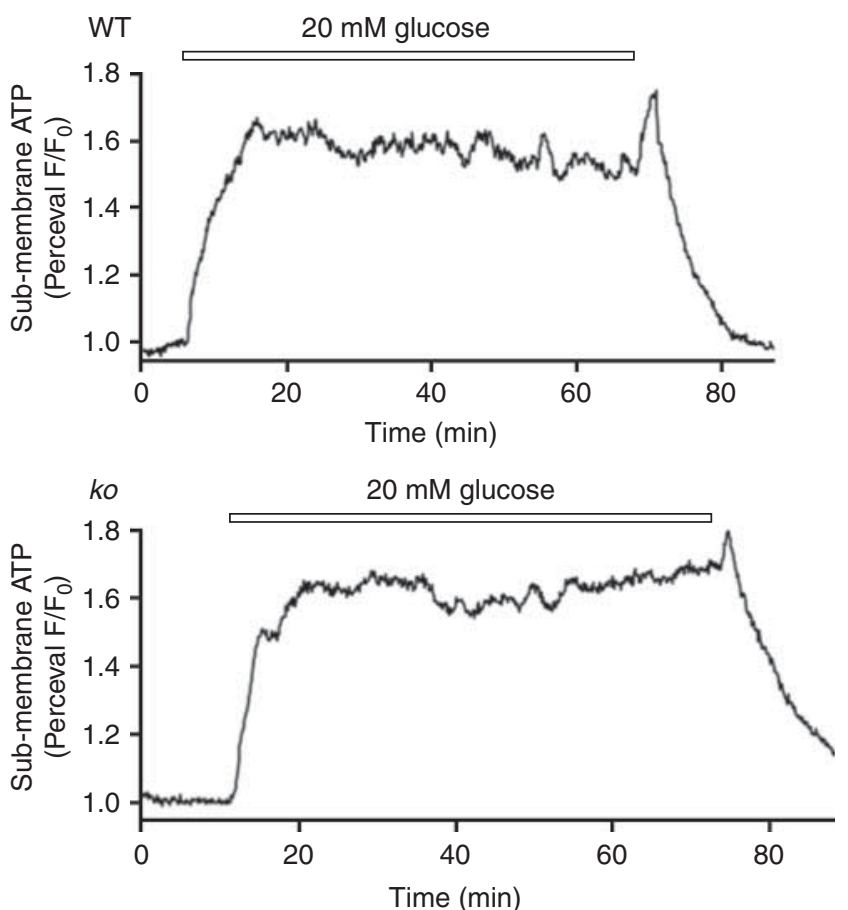

Figure 3

Glucose-induced ATP generation in WT and Shb-knockout islets. Representative TIRF microscopy recordings of the sub-membrane ATP concentration in superficially located cells in Perceval-expressing WT and $S h b$-knockout islets during an increase in the glucose concentration from 3 to $20 \mathrm{mM}$.

\section{Discussion}

Shb was originally described as a serum-inducible gene in $\beta$-cells (Welsh et al. 1994), but subsequently found to encode a ubiquitously expressed adapter protein with pleiotropic functions (Annerén et al. 2003). The multidomain structure of SHB allows the generation of signaling complexes and these can propagate signals of great diversity. A recent study has described the binding of four key $\beta$-cell transcription factors (PDX1, NKX2.2, FOXA2, and NKX6.1) to a cluster of binding sites in the SHB gene (Pasquali et al. 2014), suggesting the importance of $S h b$ in relationship with $\beta$-cell function and possibly also for the development of type 2 diabetes.

SHB has been found to interact with FAK (Holmqvist et al. 2003). It is thought that $S H B$ bridges an active tyrosine kinase receptor and FAK while simultaneously binding c-SRC, thus promoting FAK activation within this multicomponent complex (Annerén et al. 2003, Holmqvist et al. 2003). In insulin-producing cells, SHB overexpression increases the association between FAK and IRS1, thus augmenting IRS signaling (Welsh et al. 2002). Surprisingly, Shb-deficient cells commonly display elevated basal FAK activity (Funa et al. 2009, Gustafsson et al. 2013, Zang et al. 2013) with reduced ligand responsiveness, but the reason behind this response has not been clarified. One possible interpretation of those findings is that the elevated basal FAK activity is an adaptive response to loss of the ability of ligands to induce FAK activation, although it is also possible that SHB associates with or regulates the activity of other signaling components that downregulate FAK activity. The presently described moderate increase in basal FAK activity is in line with studies on endothelial and hematopoietic cells demonstrating a similar effect of Shb deficiency (Funa et al. 2009, Gustafsson et al. 2013).

The increases in IRS2 and AKT activities are likely the consequences of elevated FAK phosphorylation (Cai et al. 2012). Absence of $S h b$ renders $\beta$-cells less prone to apoptosis upon cytokine exposure and this is likely due to the
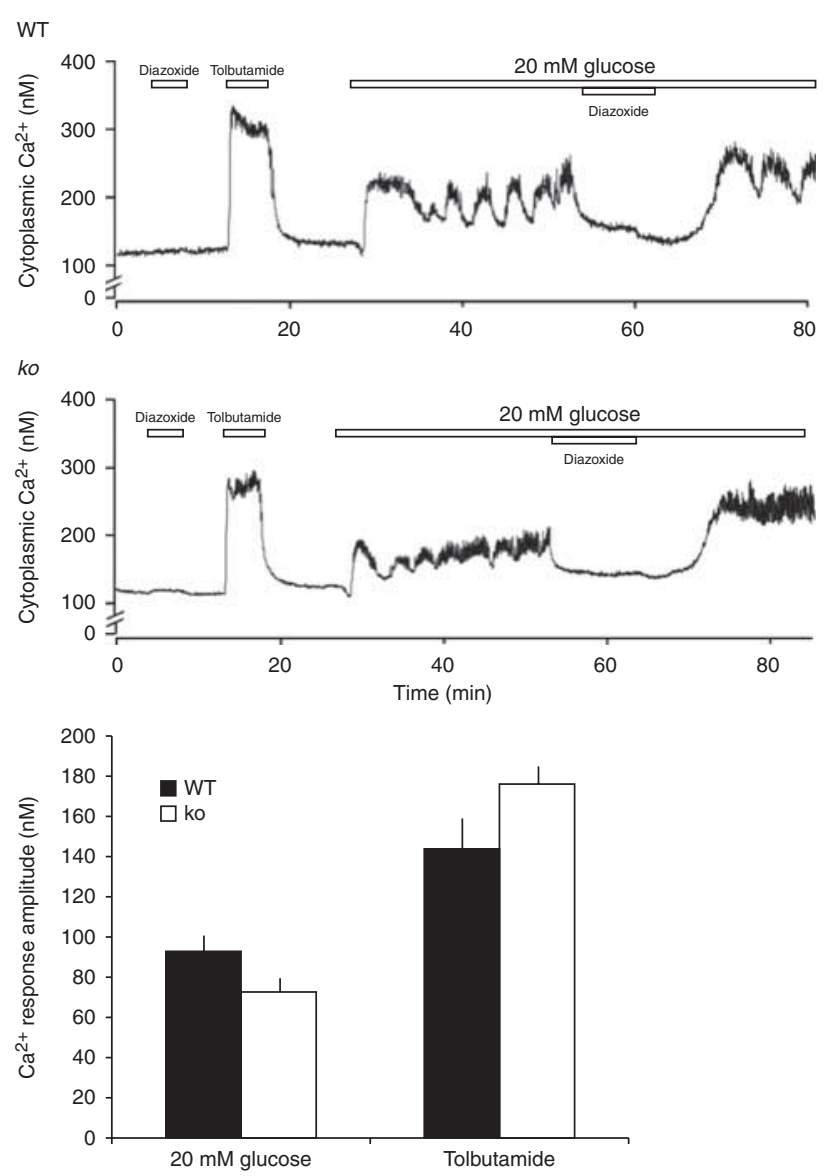

Figure 4

$\left[\mathrm{Ca}^{2+}\right]_{\mathrm{i}}$ recordings from WT and Shb-knockout islets. The islets were sequentially exposed to $0.25 \mathrm{mM}$ diazoxide, $1 \mathrm{mM}$ tolbutamide, and $20 \mathrm{mM}$ glucose as indicated. The bar diagram shows means \pm s.E.M. for the amplitudes of the initial glucose- and tolbutamide-triggered $\left[\mathrm{Ca}^{2+}\right]_{\mathrm{i}}$ increases from four to eight experiments. Basal $\left[\mathrm{Ca}^{2+}\right]_{i}$ was $114 \pm 8 \mathrm{nM}$ for WT and $92 \pm 6 \mathrm{nM}$ for Shb-knockout. 


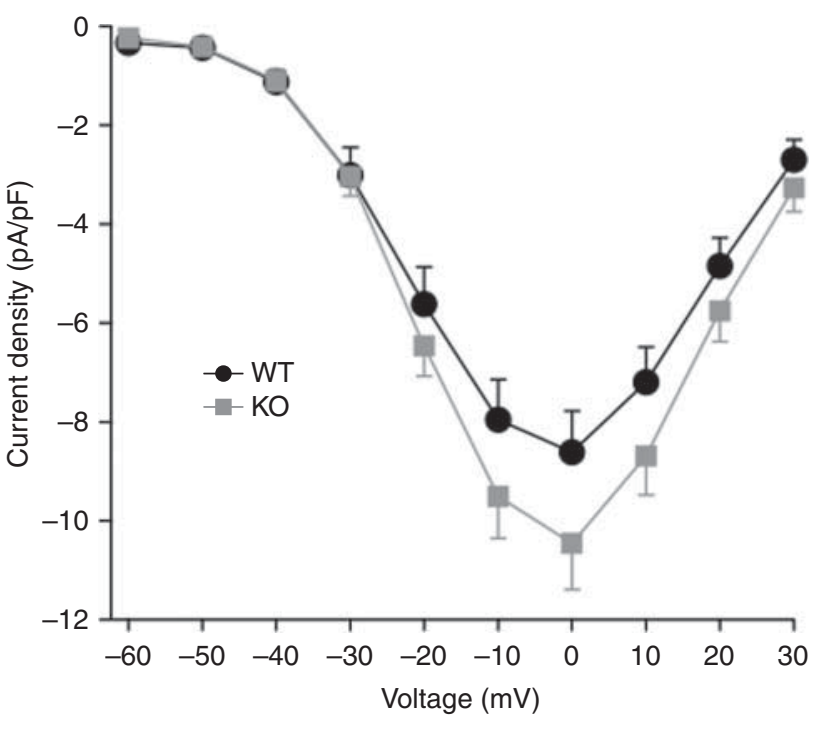

Figure 5

$\mathrm{Ca}^{2+}$-channel activity in WT and Shb-knockout islets. The data points show the average \pm s.E.M. whole-cell current response from WT ( $n=7$, black circle) and $\mathrm{KO}(n=10$, gray square) cells. The holding potential was $-60 \mathrm{mV}$ and the test pulse was applied for $200 \mathrm{~ms}$.

activation of AKT (Bernal-Mizrachi et al. 2001, Elghazi et al. 2007). One consequence of AKT activation is phosphorylation of the $\beta$-catenin regulator GSK-3b, leading to increased expression of $\beta$-catenin and its nuclear translocation (Elghazi et al. 2007). This will participate in the anti-apoptotic effect of AKT via changes in gene transcription (Elghazi et al. 2007).

Even if the expression of many genes can be expected to be altered as a consequence of $S h b$-gene knockout and the associated increase in FAK and AKT activities, we did not find changes in the expression of genes directly involved in the exocytosis machinery, suggesting that alterations in insulin secretion had other causes. Investigation of stimulus-secretion coupling by live-cell imaging of various signaling events showed that glucose-induced ATP formation and voltage-dependent $\mathrm{Ca}^{2+}$ influx were normal in $S h b$-knockout $\beta$-cells. Instead, the most striking finding in these cells was delayed glucose-induced cAMP production. Since cAMP is crucial not only in amplification of insulin secretion by incretin hormones, but also for the normal glucose-induced insulin secretory response (Dyachok et al. 2008), we suggest that this defect may explain the reduced first-phase insulin secretion in the absence of $S h b$. The mechanism underlying the altered cAMP signaling is unknown. However, it is interesting to note that a consequence of elevated FAK activity is the recruitment of phosphodiesterase 4D5 to focal adhesions, invoking a decreased cAMP concentration in the submembrane compartment adjacent to focal adhesions (Serrels et al. 2010, 2011). A similar mechanism whereby FAK regulates the submembrane cAMP concentration may be present also in $\beta$-cells and FAK-inhibition was accordingly found to cause an increase in the basal cAMP concentration, possibly by release of phosphodiesterases from the dissolving focal adhesions.

FAK has been shown to exert positive cues in glucosestimulated insulin secretion (Rondas et al. 2011, 2012, Cai et al. 2012, Arous et al. 2013), but the present data indicate that FAK may serve an inhibitory role in this process as well. FAK inhibition reduced both first- and second-phase glucose-stimulated insulin secretion and reduced the number of docked granules (Rondas et al. 2011, 2012), indicating that the prevailing effect of FAK is to promote the exocytotic process. Shb-knockout islets exhibiting elevated basal FAK activity, on the other hand, display elevated basal insulin secretion, reduced firstphase secretion, and reduced numbers of docked granules (Åkerblom et al. 2009), suggesting that the dual effect of FAK becomes most apparent when related with the significant reduction in first-phase secretion noted in the Shb-knockout system. This would imply that chronic FAK
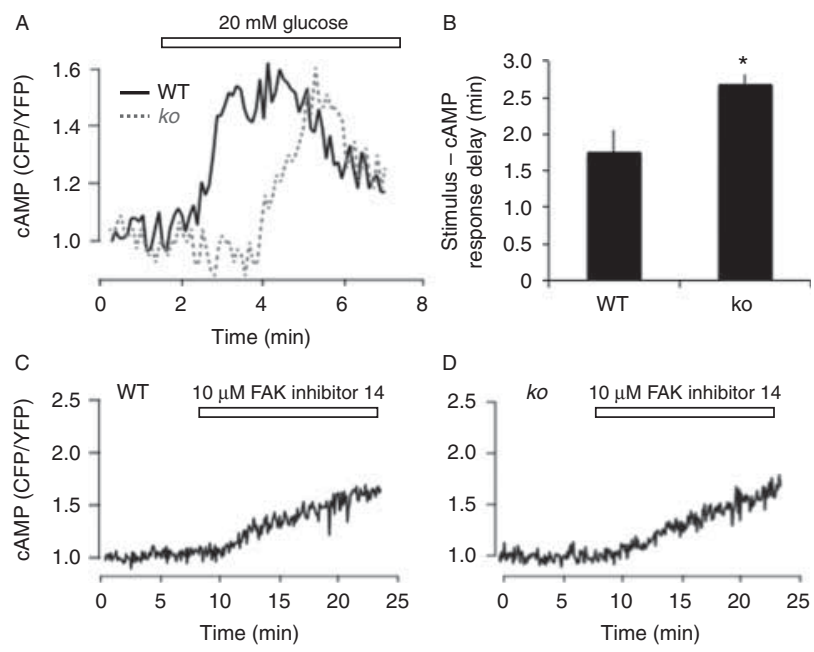

\section{Figure 6}

Delayed increase in CAMP in response to $20 \mathrm{mM}$ glucose in Shb-knockout islets. (A) TIRF microscopy recordings of the sub-membrane CAMP concentration in single cells within intact WT (black trace) and Shb knockout (dashed gray trace) islets during increase in the glucose concentration from 3 to $20 \mathrm{mM}$. (B) Quantification of the delay between glucose stimulation and rise in CAMP in WT and Shb-knockout islet cells. Means \pm s.E.M. for six separate experiments are shown. ${ }^{\star} P<0.05$ with an unpaired Student's $t$-test. (C) Effect of $10 \mu \mathrm{M}$ of FAK inhibitor 14 on CAMP in a WT islet exposed to $3 \mathrm{mM}$ glucose. (D) Corresponding results from a Shb-knockout islet. 
stimulation exerts compensatory changes that are detrimental to the first-phase secretory process, whereas stimulatory effects of FAK prevail under the other situations. The most apparent consequence of the altered FAK response in the $S h b$-knockout islets is the delayed cAMP response to glucose-stimulation, providing a plausible explanation for the reduced first-phase response.

In summary, the absence of $\operatorname{Shb}$ causes a chronic activation of FAK by an unknown mechanism. This will change certain signaling characteristics, such as activation of IRS 2, AKT, and $\beta$-catenin. The $\beta$-cell undergoes adaptive responses with reduced cell toxicity and first-phase glucose-induced insulin secretion. The latter seems to be a consequence of FAK-mediated suppression of submembrane cAMP signaling.

\section{Declaration of interest}

The authors declare that there is no conflict of interest that could be perceived as prejudicing the impartiality of the research reported.

\section{Funding}

The study was supported by grants from the Swedish Diabetes Fund, the Swedish Cancer Fund, the Family Ernfors Fund, the Novo-Nordisk Foundation, EFSD/MSD, and the Swedish Research Council.

\section{Author contribution statement}

A T and $M$ W designed the experiments, I A, O D, G T, J L, S M, Y J, and M W performed the experiments, I A, O D, G T, Y J, B B, A T, and M W analyzed the data and A T and M W wrote the paper.

\section{Acknowledgements}

The authors are grateful to Dr Sebastian Barg for suggestions and discussion.

\section{References}

Åkerblom B, Barg S, Calounova G, Mokhtari D, Jansson L \& Welsh M 2009 Impaired glucose homeostasis in Shb ${ }^{-1-}$ mice. Journal of Endocrinology 203 271-279. (doi:10.1677/JOE-09-0198)

Annerén C 2002 Dual role of the tyrosine kinase GTK and the adaptor protein SHB in $\beta$-cell growth: enhanced $\beta$-cell replication after $60 \%$ pancreatectomy and increased sensitivity to streptozotocin. Journal of Endocrinology 172 145-153. (doi:10.1677/joe.0.1720145)

Annerén C, Lindholm CK, Kriz V \& Welsh M 2003 The FRK/RAK-SHB signaling cascade: a versatile signal-transduction pathway that regulates cell survival, differentiation and proliferation. Current Molecular Medicine 3 313-324. (doi:10.2174/1566524033479744)

Arous C, Rondas D \& Halban PA 2013 Non-muscle myosin IIA is involved in focal adhesion and actin remodelling controlling glucose-stimulated insulin secretion. Diabetologia 56 792-802. (doi:10.1007/s00125-0122800-1)
Baron V, Calleja V, Ferrari P, Alengrin F \& Van Obberghen E 1998 p125Fak focal adhesion kinase is a substrate for the insulin and insulin-like growth factor-I tyrosine kinase receptors. Journal of Biological Chemistry 273 7162-7168. (doi:10.1074/jbc.273.12.7162)

Bernal-Mizrachi E, Wen W, Stahlhut S, Welling CM \& Permutt MA 2001 Islet $\beta$ cell expression of constitutively active $\mathrm{Akt} 1 / \mathrm{PKB} \alpha$ induces striking hypertrophy, hyperplasia, and hyperinsulinemia. Journal of Clinical Investigation 108 1631-1638. (doi:10.1172/JCI200113785)

Cai EP, Casimir M, Schroer SA, Luk CT, Shi SY, Choi D, Dai XQ, Hajmrle C, Spigelman AF, Zhu D et al. 2012 In vivo role of focal adhesion kinase in regulating pancreatic $\beta$-cell mass and function through insulin signaling, actin dynamics, and granule trafficking. Diabetes $\mathbf{6 1}$ 1708-1718. (doi:10.2337/db11-1344)

Dyachok O, Idevall-Hagren O, Sågetorp J, Tian G, Wuttke A, Arrieumerlou C, Akusjärvi G, Gylfe E \& Tengholm A 2008 Glucose-induced cyclic AMP oscillations regulate pulsatile insulin secretion. Cell Metabolism 8 26-37. (doi:10.1016/j.cmet.2008.06.003)

Elghazi L, Rachdi L, Weiss AJ, Cras-Meneur C \& Bernal-Mizrachi E 2007 Regulation of $\beta$-cell mass and function by the Akt/protein kinase B signalling pathway. Diabetes, Obesity \& Metabolism 9(Suppl 2) 147-157. (doi:10.1111/j.1463-1326.2007.00783.x)

Funa NS, Kriz V, Zang G, Calounova G, Åkerblom B, Mares J, Larsson E, Sun Y, Betsholtz C \& Welsh M 2009 Dysfunctional microvasculature as a consequence of shb gene inactivation causes impaired tumor growth. Cancer Research 69 2141-2148. (doi:10.1158/0008-5472.CAN-08-3797)

Golubovskaya VM, Nyberg C, Zheng M, Kweh F, Magis A, Ostrov D \& Cance WG 2008 A small molecule inhibitor, 1,2,4,5-benzenetetraamine tetrahydrochloride, targeting the y397 site of focal adhesion kinase decreases tumor growth. Journal of Medicinal Chemistry $\mathbf{5 1}$ 7405-7416. (doi:10.1021/jm800483v)

Grynkiewicz G, Poenie M \& Tsien RY 1985 A new generation of $\mathrm{Ca}^{2+}$ indicators with greatly improved fluorescence properties. Journal of Biological Chemistry 260 3440-3450.

Gustafsson K, Heffner G, Wenzel PL, Curran M, Grawe J, McKinneyFreeman SL, Daley GQ \& Welsh M 2013 The Src homology 2 protein Shb promotes cell cycle progression in murine hematopoietic stem cells by regulation of focal adhesion kinase activity. Experimental Cell Research 319 1852-1864. (doi:10.1016/j.yexcr.2013.03.020)

Hammar E, Parnaud G, Bosco D, Perriraz N, Maedler K, Donath M, Rouiller DG \& Halban PA 2004 Extracellular matrix protects pancreatic $\beta$-cells against apoptosis: role of short- and long-term signaling pathways. Diabetes 53 2034-2041. (doi:10.2337/diabetes.53.8.2034)

Henquin JC 2009 Regulation of insulin secretion: a matter of phase control and amplitude modulation. Diabetologia 52 739-751. (doi:10.1007/ s00125-009-1314-y)

Holmqvist K, Cross M, Riley D \& Welsh M 2003 The Shb adaptor protein causes Src-dependent cell spreading and activation of focal adhesion kinase in murine brain endothelial cells. Cellular Signalling 15 171-179. (doi:10.1016/S0898-6568(02)00076-1)

Idevall-Hagren O, Barg S, Gylfe E \& Tengholm A 2010 cAMP mediators of pulsatile insulin secretion from glucose-stimulated single $\beta$-cells. Journal of Biological Chemistry 285 23007-23018. (doi:10REF13=10. 1016/j.yexcr.2013.03.020)

Kriz V, Mares J, Wentzel P, Funa NS, Calounova G, Zhang XQ, ForsbergNilsson K, Forsberg M \& Welsh M 2007 Shb null allele is inherited with a transmission ratio distortion and causes reduced viability in utero. Developmental Dynamics 236 2485-2492. (doi:10.1002/dvdy.21257)

Mokhtari D, Åkerblom B, Mehmeti I, Wang X, Funa NS, Olerud J, Lenzen S, Welsh N \& Welsh M 2009 Increased Hsp70 expression attenuates cytokine-induced cell death in islets of Langerhans from Shb knockout mice. Biochemical and Biophysical Research Communications $\mathbf{3 8 7}$ 553-557. (doi:10.1016/j.bbrc.2009.07.051)

Parsons JT 2003 Focal adhesion kinase: the first ten years. Journal of Cell Science 116 1409-1416. (doi:10.1242/jcs.00373)

Pasquali L, Gaulton KJ, Rodriguez-Segui SA, Mularoni L, Miguel-Escalada I, Akerman I, Tena JJ, Moran I, Gomez-Marin C, van de Bunt M et al. 2014 
Pancreatic islet enhancer clusters enriched in type 2 diabetes riskassociated variants. Nature Genetics 46 136-143. (doi:10.1038/ng.2870)

Rondas D, Tomas A \& Halban PA 2011 Focal adhesion remodeling is crucial for glucose-stimulated insulin secretion and involves activation of focal adhesion kinase and paxillin. Diabetes 60 1146-1157. (doi:10.2337/ db10-0946)

Rondas D, Tomas A, Soto-Ribeiro M, Wehrle-Haller B \& Halban PA 2012 Novel mechanistic link between focal adhesion remodeling and glucose-stimulated insulin secretion. Journal of Biological Chemistry $\mathbf{2 8 7}$ 2423-2436. (doi:10.1074/jbc.M111.279885)

Rorsman P \& Braun M 2013 Regulation of insulin secretion in human pancreatic islets. Annual Review of Physiology 75 155-179. (doi:10.1146/annurev-physiol-030212-183754)

Serrels B, Sandilands E, Serrels A, Baillie G, Houslay MD, Brunton VG, Canel M, Machesky LM, Anderson KI \& Frame MC 2010 A complex between FAK, RACK1, and PDE4D5 controls spreading initiation and cancer cell polarity. Current Biology 20 1086-1092. (doi:10.1016/j.cub. 2010.04.042)

Serrels B, Sandilands E \& Frame MC 2011 Signaling of the direction-sensing FAK/RACK1/PDE4D5 complex to the small GTPase Rap1. Small GTPases 2 54-61. (doi:10.4161/sgtp.2.1.15137)
Tian G, Sandler S, Gylfe E \& Tengholm A 2011 Glucose- and hormoneinduced cAMP oscillations in $\alpha$ - and $\beta$-cells within intact pancreatic islets. Diabetes $601535-1543$. (doi:10.2337/db10-1087)

Welsh M, Mares J, Karlsson T, Lavergne C, Breant B \& Claesson-Welsh L 1994 Shb is a ubiquitously expressed Src homology 2 protein. Oncogene 9 19-27.

Welsh M, Christmansson L, Karlsson T, Sandler S \& Welsh N 1999 Transgenic mice expressing Shb adaptor protein under the control of rat insulin promoter exhibit altered viability of pancreatic islet cells. Molecular Medicine 5 169-180. (doi:10.1007/s008940050116)

Welsh N, Makeeva N \& Welsh M 2002 Overexpression of the Shb SH2 domain-protein in insulin-producing cells leads to altered signaling through the IRS-1 and IRS-2 proteins. Molecular Medicine 8 695-704.

Woodgett JR 2005 Recent advances in the protein kinase B signaling pathway. Current Opinion in Cell Biology 17 150-157. (doi:10.1016/j.ceb. 2005.02.010)

Zang G, Christoffersson G, Tian G, Harun-Or-Rashid M, Vagesjo E, Phillipson M, Barg S, Tengholm A \& Welsh M 2013 Aberrant association between vascular endothelial growth factor receptor-2 and VE-cadherin in response to vascular endothelial growth factor-A in Shb-deficient lung endothelial cells. Cellular Signalling 25 85-92. (doi:10.1016/ j.cellsig.2012.09.018)

Received in final form 25 September 2014

Accepted 1 October 2014

Accepted Preprint published online 1 October 2014
C 2014 Society for Endocrinology Printed in Great Britain
Published by Bioscientifica Ltd. 